\title{
Cost Returns and Input Use Pattern for China Aster Cultivation in Chikkaballapura District of Karnataka, India
}

\author{
R. Raghupathi*, G. S. Mahadevaiah, M. J. Anjan Kumar and G. M. Gaddi \\ Department of Agricultural Economics, College of UAS, GKVK Bengaluru-560065, India \\ *Corresponding author
}

\section{A B S T R A C T}

\begin{tabular}{|l|}
\hline Ke y w or d s \\
$\begin{array}{l}\text { Descriptive } \\
\text { statistics analysis } \\
\text { cost and returns }\end{array}$ \\
\hline Article Info \\
\hline $\begin{array}{l}\text { Accepted: } \\
\text { 12 February 2020 } \\
\text { Available Online: } \\
\text { 10 March 2020 }\end{array}$ \\
\hline
\end{tabular}

The present study is an attempt to estimate the cost returns and input use pattern of China aster producing farms in Chikkaballapura district of Karnataka, where China aster is cultivated extensively. Descriptive statistics were used for estimating the input use pattern of cultivation of Arka kamini and Arka Poornima variety of China aster farmers. The study is based on the primary data collected from 70 randomly chosen China aster cultivators comprising of 35 sample farmers each growing Arka kamini and Arka Poornima varieties of China aster. The results revealed that farmers realized 12 per cent higher gross returns (Rs. 2,56,500 acre ${ }^{-1}$ ' from cultivation of Arka kamini crop compared the cultivating check variety (Rs. 2,25,750acre $\left.{ }^{1}\right)$ which indicated cultivation of Arka kamini was more efficient compared to check variety. The results of the descriptive statistics analysis shows that the human labor, machine labor, seedlings, chemical fertilizers and plant protection chemicals of Arka Kamini variety was Rs. 11,012, 908 5,225 3,865 and 2,790 per acre respectively while in case of check variety was Rs. 9,842, 571, $6,588,2,400$, and 2,756 per acre respectively.

\section{Introduction}

China aster [Callistephus chinensis(L.)Nees.] belongs to the family Asteraceae and is native of China. The genus Callistephusderives its name from two Greek words 'Kalistos' and 'Stephos' means 'most beautiful' and 'a crown', respectively. China aster is one of the most preferred flower crops cultivated widely due to its wide spectrum of attractive colours and comparatively longer vase life (Chaitra and Patil, 2007). It is an important commercially cultivated flower crop grown as cut flower, loose flower, bedding plant, for flower decoration, for preparation of bouquets and garlands. The flowers of China aster are used for flower arrangement, interior decoration, garland making, worshipping (Munikrishnappa, 2013).

In addition to its cultivation, China aster can be used in landscape gardening to provide mass aesthetic effect. It is estimated to be grown in 1,020 ha with a production of flower 
800 million tonnes in India. China aster is commercially grown by marginal and small farmers in Karnataka, Tamil Nadu, Andhra Pradesh, Maharashtra and West Bengal (Raghava, 1984). This crop can be grown throughout the year under Bangalore conditions (Rao et al., 1997).

\section{Technology profile}

In India, breeding in China aster was first pioneered by S.S. Negi and S.P.S Raghava during 1984-85. Work on this aspect at ICAR-IIHR, Bangalore led to the development of quality and high yielding varieties such as Arka Kamini, Arka Poornima, Arka Shashank and Arka Violet Cushion. Suneetha et al., (2003) estimated genetic diversity of twenty eight varieties of China aster. Khangjarakpam et al., (2014) studied four China aster genotypes released from ICAR-IIHR, Bangalore such as Kamini, Poornima, Shashank and Violet Cushion and their reciprocal cross combinations viz., Kamini x Poornima, Poornima x Kamini, Shashank $\mathrm{x}$ Violet Cushion and Violet Cushion x Shashank.

The varieties grown by farmers are mainly Local Pink, Local White and Local Violet which are inferior in yield and flower quality. Hybridization is a breeding method used for developing new F1 hybrid cultivars and improves the varietal wealth, by adding new types with improved characters.

Parameters to be measured in relation to the technology

Weight of flowers/plant,

Number of flowers/plant, Flower stalk length,

Number of leaves/plant, Flower diameter,

Number of ray florets/flower head,
Number of branches/plant,

Plant height and number of disc florets/flower head.

In the present study has attempted to analyse the input use pattern, estimate the economics and constraints involved in cultivation of China aster. Findings of the study would help the followed by farmers, policy maker's researcher and to take appropriate decisions for enhancing productivity and production.

\section{Materials and Methods}

To assess the economics and input use pattern of China aster cultivation, the required primary data were collected from 70 farmers in Chikkaballapura districts of Karnataka, comprising of 35 farmers cultivating Arka Kamini and 35 farmers growing local varieties (Arka Poornima) of China aster under irrigated condition the data were collected through personnel interviews with the help of pretested schedule designed for the study.

Data were analysed using the descriptive statistics technique. Arka Kamini variety of China aster released from Indian Institute of Horticultural Research (IIHR), Bangalore is selected for the study.

\section{Descriptive statistics}

Descriptive statistics provide simple summaries about the sample and about the observations that have been made. It deals with the presentation of numerical facts, or data, in either tables or graph form, and with the methodology of analyzing the data.

\section{Input and cost concepts}

The total costs were divided into two broad categories: 
a. Variable Costs

b. Fixed Costs

\section{Variable costs}

The variable costs include cost of seeds, manure, fertilizers, wages of human and bullock labour, machine labour, plant protection chemicals, miscellaneous charges interest on working capital and repair and maintenance charges.

\section{Seeds}

The cost of purchased seeds was based on the actual amount paid by the respondents.

\section{Farm yard manure}

The quantity of FYM used in the cultivation of paddy was measured in terms of. The cost was imputed at the market price in the village including cost of transportation and other incidental charges if any.

\section{Fertilizers and plant protection chemicals}

The cost of fertilizers and plant protection chemicals was based on the actual prices paid by the farmers including the cost of transportation and other incidental charges, if any.

\section{Labour}

The cost of hired labour was calculated at the prevailing wage rates paid per day ( 8 hours) in the study area for Men, Women and Bullock labours and Machine labour during the study period. The cost of family labour human, animal and machinery) was calculated considering the prevailing market rate in this region through imputation.

\section{Miscellaneous charges}

This includes the expenses incurred by sample farmers for procuring input materials and marketing of produce in the market and other expenses.

\section{Interest on working capital}

The working capital consists of the expenditure on seeds, labour, farm yard manure, chemical fertilizers and plant protection chemicals, Interest on operational capital was calculated at the rate of 7 per cent per annum (the rate at which commercial banks advance short term loans).

\section{Fixed costs}

These include depreciation on farm implements and machinery, interest on fixed capital, land revenue.

The measurement and definitions of fixed cost components are as follows.

\section{Depreciation charges}

Depreciation on each capital equipment and machinery owned by the farmers and used for land cultivation was calculated for individual farmer based on the purchase value using the straight line method. Thus the

Annual depreciation $=$ Purchase value - Junk value

\section{Useful life of the asset}

The average life of the asset as indicated by the experts (Agril. Engineers) was used in the computation of the depreciation. The depreciation cost of each equipment was apportioned to the crop based on its percentage use.

\section{Interest on fixed capital}

Interest charges on fixed capital were calculated at the rate of 9 per cent, as the 
fixed deposits in commercial banks would fetch this rate of interest. The items considered under fixed capital are implements and machinery. Interest was considered on the value of these assets after deducting the depreciation for the year.

\section{Land revenue}

Actual land revenue paid by the farmers was considered.

\section{Rental value of land}

It was imputed by taking the prevailing rents in the study area per acre per annum.

\section{Cost of cultivation}

It is the sum of variable costs and fixed costs and expressed on per acre basis.

\section{Gross return}

The gross returns were computed by multiplying the quantity of main product and by-product obtained with respective prices received.

\section{Results and Discussion}

The Table 1 shows that total variable, fixed costs and total cost of cultivation of Arka Kamini and Arka Poornima varieties and the per cent change in these costs of Arka Kamini over the check variety. There was not much difference in case of fixed costs.

But, there was three per cent difference in case of variable costs between the two varieties i.e. Arka Kamini had three per cent higher variable costs compared to the check variety.

Overall, Arka Kamini had higher cost of cultivation i.e., 3.5 per cent higher cost of cultivation compared to the check variety. In case of variable costs, Arka Kamini had higher costs with respect to Human labour, machine labour, PPC, FYM and irrigation. While, Check variety had higher variable costs in case of seedlings and chemical fertilizers.

The increase in human labour use in Arka Kamini is, because it demands more pickings compared to check variety and lesser use of PPC is, because it is more resistant to pests and diseases compared to the check variety.

The lesser use of fertilizers is because it has higher nutrient efficiency compared to check variety. The higher seedlings use in check variety is, because survival percentage is very less in field condition.

The Table 1 depicts that the difference in yield, price per tonne and returns from Arka Kamini and Arka Poornima. Arka Kamini has higher yield, higher price per tonne, higher returns compared to the check variety.

Arka Kamini has eight per cent higher yield, 12 per cent higher gross returns, 16 per cent higher net returns and four per cent higher price per tonne compared to the check variety.

The high yield is due to the increased number of flowers per plant compared to the check variety and higher price per tonne is because it has longer vase life, its deep pink colour and demand for export to neighboring states. 
Table.1 Comparative Economics of Arka Kamini Variety and Check Variety of China aster cultivation (Rs. / acre)

\begin{tabular}{|c|c|c|c|c|c|}
\hline \multirow[t]{2}{*}{ Particulars } & \multicolumn{2}{|c|}{$\begin{array}{l}\text { Arka Kamini } \\
\qquad(n=35)\end{array}$} & \multicolumn{2}{|c|}{$\begin{array}{l}\text { Arka Poornima } \\
\qquad(\mathrm{n}=35)\end{array}$} & \multirow{2}{*}{$\begin{array}{c}\text { \% change over } \\
\text { the check } \\
\text { variety }\end{array}$} \\
\hline & quantity & $\begin{array}{l}\text { Value } \\
\text { (Rs) }\end{array}$ & quantity & $\begin{array}{l}\text { Value } \\
\text { (Rs) }\end{array}$ & \\
\hline \multicolumn{6}{|l|}{ A. Variable cost } \\
\hline Human labour(man days) & 35 & 12250 & 31 & 10850 & 11.43 \\
\hline Bullock labour(pairday) & 1.89 & 1395 & 1.58 & 1208 & 13.41 \\
\hline Machine labour(hours) & 7.2 & 6757 & 6.5 & 5857 & 13.32 \\
\hline Seedlings(Rs.) & 6123 & 7654 & 6252 & 8128 & -6.19 \\
\hline FYM(tonnes) & 6.5 & 19,500 & 6 & 18,000 & 7.69 \\
\hline Chemical fertilizer(kgs) & 180 & 2,895 & 300 & 4,350 & -50.26 \\
\hline PPC (Rs) & - & 3,000 & - & 2,500 & 16.67 \\
\hline Irrigation(inch) & 5 & 800 & 4.75 & 700 & 12.5 \\
\hline Mulching material(Rs) & - & 9,000 & - & 9,000 & 0.00 \\
\hline Transportation cost (Rs) & - & 1,500 & - & 1,400 & 6.67 \\
\hline Subtotal(Rs) & - & 64,751 & - & 61,993 & 3.26 \\
\hline Interest on working capital at 7 & \multirow[t]{2}{*}{-} & \multirow[t]{2}{*}{4,533} & \multirow[t]{2}{*}{-} & \multirow[t]{2}{*}{4,340} & \multirow[t]{2}{*}{5.16} \\
\hline$\%$ ( Rs.) & & & & & \\
\hline Total variable cost(Rs) & - & 69,284 & - & 66,333 & 3.06 \\
\hline \multicolumn{6}{|l|}{ B. Fixed cost } \\
\hline Land revenue(Rs) & - & 15 & - & 15 & 0.00 \\
\hline Depreciation(Rs) & - & 650 & - & 600 & 7.69 \\
\hline Rental value of land(Rs) & - & 15,000 & - & 15,000 & 0.00 \\
\hline Subtotal(Rs) & - & 15,665 & - & 15,615 & 0.36 \\
\hline $\begin{array}{l}\text { Interest on fixed cost at } \\
10 \%(\mathrm{Rs})\end{array}$ & - & 1,567 & - & 1,562 & 0.23 \\
\hline Total fixed cost & - & 17,232 & - & 17,177 & 0.26 \\
\hline Total cost of cultivation $(A+B)$ & - & 86,515 & - & 83,509 & 3.47 \\
\hline
\end{tabular}

Table.2 Yield and returns from China aster cultivation (Per acre)

\begin{tabular}{|l|c|c|c|}
\hline \multicolumn{1}{|c|}{ Yield and Returns } & $\begin{array}{c}\text { Arka Kamini } \\
(\mathbf{n = 3 5})\end{array}$ & $\begin{array}{c}\text { Arka Poornima } \\
(\mathbf{n = 3 5})\end{array}$ & $\begin{array}{c}\text { \%change over the } \\
\text { check variety }\end{array}$ \\
\hline Yield (Kg/acre) & 5700 & 5250 & 7.89 \\
\hline Gross Returns(Rs) & 256500 & 225750 & 11.99 \\
\hline Net returns(Rs) & 169985 & 142241 & 16.32 \\
\hline Price received (Rs/kg) & 45 & 43 & 4.44 \\
\hline Returns per rupee of investment & 2.96 & 2.70 & \\
\hline
\end{tabular}


Table.3 Input use patterns for Arka Kamini and check variety

\begin{tabular}{|l|c|c|c|c|c|c|c|c|}
\hline \multirow{2}{*}{ Variables } & \multicolumn{4}{|c|}{ Arka Kamini variety $(\mathbf{n = 3 5})$} & \multicolumn{3}{c|}{ Arka Poornima variety (n=35) } \\
\cline { 2 - 9 } & Mean & S.D & Min & max & Mean & S.D & min & max \\
\hline $\begin{array}{l}\text { area under China aster } \\
\text { (acre) }\end{array}$ & 0.87 & 0.32 & 0.5 & 1.5 & 0.9 & 0.43 & 0.5 & 2 \\
\hline Human labour(Rs) & 11,012 & 4,496 & 3,400 & 22,000 & 9,842 & 4,496 & 3,400 & 22,000 \\
\hline Machine labour (Rs) & 908 & 680 & 150 & 3,000 & 571 & 394 & 90 & 1,100 \\
\hline Seeds (Rs) & 5,225 & 2,934 & 1,725 & 15,000 & 6,588 & 5,313 & 1,725 & 27,300 \\
\hline Chemical fertilizers (Kg) & 3,865 & 1,449 & 1,350 & 7,350 & 2,400 & 1,040 & 1,000 & 4,900 \\
\hline PPC(Rs) & 2,790 & 2,744 & 600 & 16,000 & 2,756 & 2,835 & 500 & 17,550 \\
\hline Gross return (Rs) & $2,29,007$ & 70,788 & $1,15,500$ & $4,67,500$ & $2,03,035$ & $4,30,742$ & $1,12,500$ & $27,20,000$ \\
\hline
\end{tabular}

The input use pattern of Arka Kamini and check variety was showed from the Table 3. The average input i.e., human labour (Rs. 11,012) was highest in both the varieties. The average input use of Arka Kamini was more in machine labour (Rs.908), chemical fertilizers (Rs. 3,865) and plant protection chemicals (Rs. 2,790) compared to check variety. The average input use of check variety was more only in seeds (Rs.6, 588) compared to Arka Kamini variety.

The gross returns realized by the Arka Kamini farmers growing as pure crop was Rs. 2,56,500per acre whereas it was Rs. 2,25,750 by check variety (local variety of China aster) farmers with a difference of Rs. 30,750 per acre, higher than check variety of Farms. The net return of Arka Kamini was the higher (Rs. 1, 69,985 per acre) Arka Kamini of China aster farms than (Rs. 1,42,241 acre) for check variety farms, with a difference of Rs. 27,744 higher than the local variety of China aster. The results of the descriptive statistics analysis shows that the human labor, machine labor, seedlings, chemical fertilizers and plant protection chemicals of Arka kamini variety was Rs. 11,012, 908 5,225 3,865 and 2,790 per acre respectively while in case of check variety was Rs. 9,842, 571, 6,588, 2,400, and 2,756 per acre respectively.

Input use pattern have been estimated for one of the important flowers, viz. China aster using descriptive statistics analysis. The variables influencing Input use pattern the of China aster production have been analysed determined using the descriptive statistics. The input use pattern in China aster production among different categories of farmers highlighted that most of the applied inputs were found to be in lower than the recommended acreage. This suggests that there is potential to increase the overall production, by in China aster cultivation.

The Arka Kamini variety of China aster performing well in field conditions and offering higher returns to the farmers in comparison with check varieties. The main emphasis of this study is on increasing the production, income and employment opportunity at farmer's level. In this context, the study will be of great importance to recognize whether the improved IIHR (Indian Institute of Horticultural Research) technology verities is profitable and whether it has provided additional production opportunities to the technology adopters.

\section{References}

Aynul Haque, Monayem Miah, M. A. and Hossain, S., 2012, Economics of marigold cultivation in some selected areas of Bangladesh. Bangladesh J. 
Agril. Res.,37(4): 711-720.

Bahirat, J.B. and Jadhav, H.G., 2011, Cost returns and profitability of rose production in Satara District, Maharashtra. The Asian J. Hortic.,6 (2): 313-315.

Prabhakara Rao, M., Shareef, S.M. and Raju, V.T., 1992, Costs and returns of jasmine cultivation in Guntur-district, Andhra Pradesh.South Indian. J. Hort., 40(2): 100-104.

Rao, T.M., Negi, S. S. and Raghava, S.P.S.
1997, Kamini - a new China aster cultivar from IIHR, Bangalore, Floriculture Today.5 (8): 40

Suneetha, C. and Narayanaswamy, P. 2003, Estimation of genetic diversity among China aster (Callistephus chinensis (L) Nees.) varieties/accessions through RAPD markers. National Symposium on Recent Advances in Indian Floriculture, Nov.12-14, 2003, KAU, Vellanikkara.

\section{How to cite this article:}

Raghupathi. R, G. S. Mahadevaiah, M. J. Anjan Kumar and Gaddi. G. M. 2020. Cost Returns and Input Use Pattern for China Aster Cultivation in Chikkaballapura District of Karnataka, India. Int.J.Curr.Microbiol.App.Sci. 9(03): 1579-1585.

doi: https://doi.org/10.20546/ijcmas.2020.903.185 